\title{
A ESCRITA DA TESE À PROCURA DA INVESTIGAÇÃO SOBRE A VIDA: uma auto- etnografia dos processos de apropriação e ensino da escrita académica
}

\author{
Ana Luísa Paz \\ Universidade de Lisboa - ULisboa, Portugal
}

\begin{abstract}
Resumo
O artigo propõe-se realizar um auto-estudo de cariz auto-etnográfico sobre os processos de escrita académica da autora. Elege como narrativa central a sua tese de doutoramento sobre ensino de música em História da Educação, que ocupa aqui o lugar de objeto de investigação. No cruzamento entre diferentes áreas da Educação atravessadas, História, Educação Artística, Pedagogia do Ensino Superior, procura-se ver a tese como o lugar pretérito e futuro de uma escrita que está ainda a aprender a ser, mas que também se está a aprender a ensinar. Nesta análise, são desmontados os modos como se construiu uma tese de doutoramento (organização, quadro teórico e conceituação, metodologia, etc.) e apresentam-se as consequências desta tese para o presente da autora, nomeadamente na ultrapassagem de dilemas ou na consciência sobre as opções tomadas na orientação de doutoramentos e mestrados e no ensino de modos de investigar na licenciatura, onde sempre a escrita tem um lugar central.
\end{abstract}

Palavras-chave: Tese de doutoramento; Escrita académica; Auto-etnografia; História do ensino de música; Génio.

\begin{abstract}
The article proposes to carry out a self-study with an autoethnographic perspective on the author's academic writing processes. Her Ph.D thesis in History of Education about music education is chosen as the central narrative and thus takes place here as the object of investigation. At the intersection between different areas of Education crossed, History, Arts Education, Pedagogy for the Higher Education, it seeks to envision the thesis as the past and future place of a writing that is still learning to be, but that is also being learn how to teach. In this analysis, the ways in which a doctoral thesis was constructed (organization, theoretical framework and conceptualization, methodology, etc.) are disassembled and the consequences of this thesis for the author's present are presented, namely in overcoming dilemmas or awareness about the options taken in master and Ph.D supervision and in teaching ways of investigating in the undergraduate degree, where writing always has a central place
\end{abstract}

Keywords: Academic writing; Autoethnography; History of music education; Genius. 


\section{Introdução}

Tendo por base a auscultação à tese de doutoramento História do Ensino da Música em Portugal (1868-1930): Uma história de pedagogia e do imaginário musical (Paz, 2014), proponho analisar os meus processos de escrita académica, com o intuito de questionar os modos de fazer, de aprender e de ensinar a escrita científica que me constituem no tempo presente. Procuro compreender a sua translação para novos processos de escrita ${ }^{1}$, já não centrados no formato-tese, nem sequer na lesta desmultiplicação em artigos, mas num percurso de aprendizagem que agora se transforma também numa etapa de ensino.

Entre 2008 e 2014, a signatária destas páginas ocupava-se apaixonada e unicamente, com investigação e escrita de uma tese publicamente apresentada em maio de 2015. Um ano depois, em maio de 2016, com o início de funções como docente convidada no Instituto de Educação da Universidade de Lisboa, o panorama foi alterado pelo acréscimo de uma nova inquietação: o ensino. No início desta atividade profissional, essa preocupação era relativizada pelo vínculo precário, mas com o ingresso na carreira docente (em período experimental) em maio de 2019, tornou-se premente pensar como me estava a reconstruir como investigadora, de modo a poder encontrar aí um recurso para poder ensinar.

$\mathrm{Na}$ breve experiência de ensino, onde a investigação e a escrita ocuparam sempre um lugar central, contactei de perto com alunos da licenciatura (1. ${ }^{\circ}$ ano), de mestrado, de doutoramento e pós-doutoramento, heterogeneidade essa que me permitiu tomar pulso das suas dificuldades, idiossincrasias e desejos. Por mais formações, leituras e conversas que tivesse sobre a questão pedagógica, seria sempre a base experiencial, ainda fortemente condicionada pela vivência como aluna de doutoramento, que traria às minhas aulas e sessões de orientação um rumo sobre o saber-fazer da escrita académica. Trata-se, deste modo, de discutir o processo de alguém que se preparou para o trabalho da investigação e tem a tese de doutoramento como o corolário desse investimento, mas precisa de constituir, no seu interior, uma persona docente.

Pelos atravessamentos entre escrita e profissão-professor, entre devir investigador e desejo literato que aqui se trata, a tese como objeto acaba por perder a sua centralidade, dando esse lugar ao processo, tornando este artigo uma reflexão em andamento. A própria área científica de inserção original, que se situava na História da Educação, acaba por se transmutar até à zona da Educação Artística, onde reside uma parte fundamental do meu presente trabalho de pesquisa e lecionação. Ao mesmo tempo, o comprometimento com a área e com uma equipa de trabalho em Pedagogia do Ensino Superior, trouxe a possibilidade de colaborar na organização de um curso de pós-graduação e em vários projetos de intervenção e investigação. Num nó que atravessa três áreas, da História, da Educação Artística e Pedagogia do Ensino Superior, procuro refletir sobre como me posso deslocar com esta herança. É como se me tivesse atribuído o papel de genealogista do meu próprio presente e se a questão metodológica remetesse sempre para a pergunta: como cheguei até

\footnotetext{
${ }^{1}$ Este trabalho foi financiado pela FCT -Fundação para a Ciência e a Tecnologia, no âmbito da UIDEF -Unidade de Investigação e Desenvolvimento em Educação e Formação, Referência UIDB/04107/2020.
} 
aqui? Trata-se, assim, de me deslocar ao interior da experiência da história - que é a minha - para pensar sobre essa escrita, de onde vem, para onde me pode levar?, com as ferramentas conceptuais e analíticas de que disponho.

Nestas circunstâncias, o texto remete para uma auto-etnografia, que se situa na proximidade com um auto-estudo, tanto pelo modo de escalpelizar o documento-tese pelo seu embate na construção da minha subjetividade profissional, quanto pelo modo direcionar para uma superfície temporalmente fluída, onde convivem passado e futuro, e ainda pela forma como esta investigação se organiza em torno do meu processo de construção pessoal (ELLIS, 2004).

O artigo apresenta um breve enquadramento das linhas teóricas e metodológicas que suportam a leitura aqui proposta, seguindo-se uma apresentação crítica do conteúdo da tese de doutoramento, com interrupções e perfurações para o processo de escrita, tanto aquele que foi, quanto aquele que acabou por ser dali originado.

\section{Enquadramento ou rumo}

Para a elaboração deste artigo, procurou-se inicialmente pesquisar sobre diferentes modos de pensar acerca do processo da escrita académica dentro da História da Educação. Entre o trabalho e reflexão trazido muitos outros investigadores, professores e alunos, destaca-se uma discussão recente onde se discorre sobre a escrita inventiva na universidade. "Fazer a Mão" acaba por propor, a partir de Michel Foucault e de Gilles Deleuze, que o investigador se entregue a uma vida como obra de arte, em que a escrita teria o seu papel fundamental, num "vínculo a uma arte de existir que agrega pensamento, imaginação e sensibilidade" (Ó, 2019, p. 10; sublinhado no original).

É a partir deste convite que opto por fazer aqui um primeiro deslocamento sobre a área de fundamentação original da minha tese para o campo da Educação Artística, onde descubro novas ferramentas para pensar e expandir a minha escrita, operando assim um distanciamento entre a escrita consumada e o seu porvir.

Com efeito, encontro na bibliografia sobre educação e estudos artísticos uma série de problematizações, onde os autores acabam por sentir a necessidade de lateralizar e definir os problemas da escrita, separando-os do objeto tese, e fazendo emergir os temas que perturbam e bloqueiam a investigação e o cometimento à escrita. Inúmeros artigos e apresentações durante o tempo de realização da tese surgem como forma de refletir não sobre tema da tese, mas das dificuldades que enfrentam durante o processo.

Essa discussão do processo de escrita, muitas vezes acaba por ser obscurecido pelas dificuldades externas. Por exemplo, Susana Mendes Silva, na dupla condição de artista plástica e performer, ao ver-se compelida a ingressar num ciclo de doutoramento em Arte Contemporânea, configura um caso paradigmático das suas preocupações como investigadora - no prolongamento do que já fazia enquanto artista - e no embate com uma nova forma de escrita, em que não há receitas prévias (SILVA, 2016). 
Outra forma de enfrentar os problemas da escrita encontra-se na discussão minuciosa de tópicos específicos, cogitados no âmago da escrita. Aponta-se o exemplo do artigo que em português podemos ousar traduzir por "Explorando a penumbra do não-verbal: a relação entre a escrita e o fazer num Doutorado com metodologia Baseada na Prática", onde Sarah Horton (2008) discute a relação entre a teoria e prática. A autora argumenta que a teoria transporta em si mesma uma dualidade enquanto escrita e enquanto prática de tal modo que acaba por se consumar numa forma que lembra a "concertina", que em se opera uma tensão de constante abrir e fechar do fole para que a música se produza e em que "um gesto informa o outro" (HORTON, 2008, p. 187; tradução minha' ${ }^{1}$ ).

Neste embate acaba muitas vezes por irromper a criação de conceitos ou sua discussão a partir das dificuldades da escrita, tal como acontece numa estética do impasse, proposta por André Alves (2014), a partir da sua experiência de bloqueio. De acordo com a vivência que narra e problematiza, acabou por reconsiderar o impasse criativo como necessário ao processo artístico (onde a escrita também se inclui). Um exemplo muito próximo desta forma de usar as dificuldades da tese em seu favor é a conceptualização que Emma Cocker (2009) realiza a partir das notas de rodapé, usadas sua investigação para explorar "as diferentes possibilidades temporais da escrita" (COCKER, 2009, p. 139; t.m.). Tal como Susana Mendes Silva, também Cocker mostra as dificuldades de passar para a escrita a artist-led research em torno do projeto Open City (2007), mas ultrapassa essa dificuldade, tornando-a como potência da investigação. Esse volte face faz-se a partir da reconstrução da ideia de nota de rodapé "usada como um dispositivo criativo e crítico para produzir pontos de lentidão e de bloqueio no ato da leitura, ou como forma de um convite performativo que encoraja a deambulação textual e física" (COCKER, 2009, p. 139; t.m.). Como salientam as editoras da publicação, neste ensaio que "nos lança para a cidade e para as possibilidades da nota de rodapé como uma "viagem intelectual", está imerso um mesmo gesto criativo e conceptualizante da escrita, onde Cocker propõe também que as "deambulações físicas e textuais' são legítima e efetivamente "ferramentas metodológicas" (ORR; HIND, 2009, p. 135 ; t.m.).

Embora os estudos supracitados remetam para a dupla função do fazer investigativo e do fazer artístico, já se percebe que, mesmo em diferentes áreas do conhecimento, os dilemas e tensões de que a escrita académica resulta são aproximadamente as mesmas. Decorrem, essencialmente, desse corpo a corpo, duma promiscuidade que se estabelece no fazer entre ideias, técnicas e desejos, lançando o sujeito da escrita num profundo desconforto, consigo e com o que tem a dizer, pelo que não dependem estritamente de uma área de conhecimento.

O diagnóstico suspirado de não saber ou conseguir escrever, ao qual sempre chega o aluno de doutoramento, nada tem de novidade. Remete para o que há mais de um século o "mestre do eterno retorno" (NIETZSCHE, 1988, p. 119), como o próprio se autodesignava, apontara como uma falha no sistema educativo alemão - mas que podemos facilmente estender para ambientes mais próximos: "Nenhuma forma de dança se pode retirar da educação superior: a dança com os pés, com os conceitos, com as palavras; terei ainda de dizer que importa também dançar com a pena, isto é, que se deve aprender a escrever?" (NIETZSCHE, 1988, p. 68). 
Desde a fundação da Universidade de Berlim o modelo proposto Humboldt impôs-se pela dupla missão da universidade, de ensinar e de investigar. Apesar disso, não existe nenhum cometimento global, nacional ou institucional que tivesse como bandeira transformar o ensino superior uma escola de escrita, pese embora as muitas afirmações pessoais ou dentro de pequenos grupos. Jorge Ramos do Ó discute como vários académicos e eruditos, ao longo a história, procuraram ao mesmo tempo problematizar e ensinar a escrita, partindo sempre da desvantagem naturalizada da escrita em relação ao registo oral (Ó, 2019). Como o autor demonstra, até à época moderna e à plena divulgação do livro impresso, os principais recursos dos escritores foram sempre técnicas como a imitatio ou a manutenção de livros de lugares-comuns. $\mathrm{O}$ abandono do ensino destes recursos de cariz oficinal abriu um vazio que, até aos nossos dias, nunca se tentou preencher. Muitas tentativas de autores vários e de professores universitários procuraram, ainda assim, mostrar os seus processos de escrita e como a escrita é mobilizada para a investigação, senão mesmo para a criação, dos seus objetos de estudo.

É neste sentido que a linha de estudos de Pedagogia do Ensino Superior remete para uma lacuna que me interessa explorar sobre as formas de ensino da chamada escrita académica. Facilmente, os processos de escrita têm sido tratados a partir de receituários e metodologias, mais ou menos institucionalizadas. Bastaria pesquisar no motor de busca google esta expressão, para obter de imediato manuais de estilo, muitos deles associados a normas de referenciação que se impuseram no mercado académico como legítimas e legitimadoras.

A investigação sobre a escrita praticada e ensinada na universidade, no entanto, tem procurado, de modo geral, contrariar e suspender esta questão, ao tentar verificar o que se passa concretamente em sala de aula, de acordo com diferentes níveis de ensino e nas diversas áreas do conhecimento. Deste modo, culturas locais e soluções particulares têm transitado no ensino superior como possibilidades ao dispor de toda a comunidade.

Recordo entre os diversos exemplos que Biesta tem trazido a lume, um artigo provocador sobre o modo como o pedagogo procurou que os seus alunos incorporassem conceitos: depois de terem recebido um papel com um conceito escrito, tiveram de circular com esse papel durante alguns dias, findos os quais foram convidados a refletir sobre esse conceito (BIESTA, 2014). Após uma análise dos testemunhos, depreende que seria possível libertar o ensino da aprendizagem, de modo a proporcionar novas aberturas na relação educativa travada no ensino superior, já não fundadas no academicismo, mas numa profunda exploração dos processos de pensamento e conceptualização pura, em remissão para gestos eminentemente inventivos. Nesta linha de pensamento, escrita descola-se do peso de tecnicismo que, em boa verdade, só se ensina pela rama, e passa a estar interiorizada nos próprios processos de subjetivação dos alunos, no seu quotidiano e em todas as formas que estabelecem para conhecer e pensar o mundo. Escrita torna-se assim inseparável da existência.

É neste percurso e com esta inquietação que atravessa a História da Educação, a Educação Artística e a Pedagogia do Ensino Superior que importa perguntar, enquanto autora da tese de doutoramento História do Ensino da Música em Portugal (1868-1930): Uma 
história de pedagogia e do imaginário musical (Paz, 2014), como este processo de escrita me constitui como investigadora e como professora, no passado, no presente e, quem sabe, numa direção para o futuro.

\section{Notas para uma metodologia}

Enfrentar a escrita sobre a escrita sem cair numa metanarrativa circular e narcísica é talvez das tarefas mais difíceis que podem caber a quem se entregar a esse árduo desígnio. Para evitar essa armadilha sempre à espreita, é essencial apontar para uma metodologia capaz de dar conta do regresso à tese, com suas vivências e intensidades adjacentes. Tomo de empréstimo as palavras de uma educadora artística nova-iorquina de origem austríaca, que procurou através da auto-etnografia compreender o seu percurso profissional e que, quanto a mim, define o essencial desta metodologia:

Auto-etnografia é uma forma de auto-entendimento que encoraja o investigador a abrir a sua estória, de modo a conectá-la com questões sócio-culturais e políticas mais vastas da sociedade (ELLIS, 2004). À medida que olha para trás, o/a investigador/a expande o seu horizonte para mapear uma direção futura” (RIEDLER, 2016, p. 139-140).

Uma auto-etnografia justifica-se, assim, pela necessidade de mergulhar numa subjetividade que não se deseja nem é desejável combater, mas de, ao mesmo tempo, empreender uma reflexão informada que, sem pretensões a uma "ilusória universalidade", seja capaz de falar a outrem (FORTIN, 2009, p. 84). Aduzo ainda uma terceira razão, que advém de imperiosidade metodológica mais profunda, que passa por usar este texto como laboratório de experimentação de uma forma de investigar sobre a qual ensino, tanto em aulas como em orientações de mestrado e doutoramento, mas à qual raramente me submeti, e nunca até às últimas consequências.

Neste sentido, a própria escolha de uma metodologia é já um entendimento autoetnográfico da pesquisa, em que se fazem presentes os princípios éticos e políticos que devem subjazer a uma investigação deste género. Reconheço que esta metodologia, da qual ainda me estou a apropriar, passou a fazer parte do meu universo só após o labor docente. A aprendizagem com os alunos em decorrência de um desconhecimento inicial ou específico, na prática, remete para um tabu de explicitação (BOURDIEU, 2008b), mas começa a ser combatido pelo novo paradigma de universidade. A demanda de teses de mestrado e de doutoramento em ciclos curtos de dois e três anos, respetivamente, tem por consequência que os orientadores precisam do contacto com os alunos para garantirem uma atualização na revisão de literatura, métodos e abordagens (HALSE, 2011, p. 565).

Conhecer e explorar esta metodologia que se estabeleceu entre a antropologia crítica dos anos 1970 - então a auto-etnografia, uma etnografia em que o investigador e o investigado se confundiam, mas sem estabelecer ainda um método de pleno - e que hoje deriva numa metodologia autónoma, com formas de investigação e redação muito complexas (ADAMS; HERMANN, 2000, p. 2), implicou, no meu caso, uma atenção aos trabalhos realizados no 
foro dos estudos em Educação Artística. Por ser uma área científica recente, também a autoetnografia aí se aloja a partir de novas tendências epistémicas, em que a subjetividade passa a estar complemente no centro do ato de conhecimento, e em que as formas artísticas são integradas no processo investigativo. Nesta perspetiva, envidei a sua experimentação em explorações pessoais sobre o trabalho numa disciplina (PAZ, 2020) e a pares, na continuação de uma investigação colaborativa sobre uma prática de co-docência (PAZ; CAETANO; 2020). Em ambos os casos, o problema da escrita e do ensino da escrita científica foi sempre central.

Tal como nesses estudos anteriores, também aqui a auto-etnografia não foi ainda levada até às suas últimas consequências, nomeadamente numa interiorização do autor como verdadeiro sujeito do conhecimento e do quotidiano como um autêntico manancial para a construção do conhecimento científico. Esse retraimento - já de si significativo - é amparado por uma postura de entrelaçamento com um auto-estudo e de criação e análise de uma narrativa (HAMILTON et al, 2008)

A tese de doutoramento surge como uma narrativa manufaturada, que congrega uma série de saberes, conhecimentos e experiências. Ao mesmo tempo, implica uma nova dimensão de tempo, o tempo que essa narrativa representa na vida, entretanto continuada, de alguém que além de investigar passou a ter a função de ensinar, e com isso conquistou terreno para novas narrativas. Por essa razão, a tese é pensada como objeto, na medida em que contém uma narrativa implícita sobre a sua escrita, narrativa essa que se desenvolve em meio a um arquivo mais denso, onde se contam inúmeros outros documentos: relatórios, versões provisórias, esquemas, desenhos, arquivos de fontes, cadernos de notas, diários de campo, fotografias, e-mails e mensagens trocadas. Arquivo é então o que resta de um tempo-outro, e que aqui se convoca como uma camada que antecede a obra final, mas também detalha os documentos que mostram como essa tese foi feita. É também um arquivo do que vem depois, e que se constrói na minha narrativa desses acontecimentos, e de outros documentos entretanto gerados: diário profissional, materiais pedagógicos, recortes, notas, artigos e trabalhos científicos. Nesta rede infindável de documentação que foi preciso localizar e selecionar, começa então a tecer-se uma compreensão do processo de escrita científica e da passagem para possíveis formas de ensinar, algumas já em forma tentada, outras apenas em esboço e devir.

\section{Breve apresentação: uma narrativa sobre a narrativa-tese}

Só alguns aprendem a cantar, tocar um instrumento, compor. E se tal acontecesse não por uma decorrência natural ou por um processo social complexo, mas, muito mais simplesmente, por uma ideia profundamente enraizada na sociedade moderna? Digamos, a ideia de que o ensino musical deve ser reservado aos que demonstram a possibilidade de se tornarem... génios? (PAZ, 2014, p. 1; sublinhado no original). 
Assim começa a longa dissertação sobre a História do Ensino da Música em Portugal (PAZ, 2014), que se espraia por 727 páginas, mais bibliografia e outras tantas centenas de páginas de anexos remetidos para suporte digital. Voltar a este volume cinco anos depois de finalizado o ciclo de doutoramento é chegar a um lugar estranho, irreconhecível e exterior. Diante da obra acabada, já muitas vezes consultada e por isso anotada e revista, vai-se recuperando uma familiaridade entretanto perdida.

O primeiro movimento de perscrutar parte, por isso, de um folhear que se guia pelo índice e pela sequência do texto. Opto por apresentar aqui o texto nas suas traves mestras para depois o procurar desconstruir e encontrar outras leituras e atravessamentos. Sigo, neste passo, a ordem do texto, de modo a fornecer ao/à leitor/a uma panorâmica da tese, para mais adiante passar a uma análise mais específica e detalhada das diferentes partes que me interessa recortar, sempre em prol da ideia de escrita científica.

O índice revela um texto muito dividido, com uma introdução, parte teórica e parte empírica, um fecho, referências e cinco anexos. Surge assim um singelo "Enquadramento teórico", que configura a parte I, e um "Estudo empírico", que organiza a parte II.

Na parte I, procurei plasmar os mais importantes estudos percorridos e os deslocamentos que, com eles, fui experimentando. Compus o texto em dois capítulos. "Sujeito musical moderno", o primeiro deles, apresentava a justificativa do tema e a pergunta inicial ("porque não aprendemos todos/as música?"), além de uma revisão da literatura, que desemboca na pergunta de investigação: "de que modo a ideia de génio se constituiu no imaginário musical e de que modo funcionou no ensino musical português entre 1868 e 1930?" (Paz, 2014, p. 23 e 66; sublinhado no original). Esta forma de organização mimetizada de outras dissertações - embora ao momento da redação não o suspeitasse - enquadra-se no desenho proposto por Quivy e Campenhoudt (1992, p. 27-44), conforme ensinei em anos seguintes, na unidade curricular de Introdução à Investigação em Educação.

No segundo capítulo são quatro os subcapítulos que organizam uma "desnaturalização do sujeito moderno", seguindo este roteiro: 1) uma discussão sobre a discussão do tema na historiografia, 2) uma genealogia do conceito de génio - central para todo o trabalho -, 3) um mapeamento teórico de outros conceitos operativos (e.g., capital cultural), e, por último, 4) uma exposição das apropriações que previamente havia experimentado com estes conceitos.

Na parte II, o "Estudo empírico" subdivide-se novamente em quatro parcelas, que se enceta com uma primeira apresentação geral, que abre para três capítulos empíricos. Cada um destes capítulos encerra uma discussão sobre aqueles que foram considerados os três principais eixos da ação do sujeito: o eixo dos discursos, "onde se conceberam os principais saberes que deveriam orientar a prática musical e a sua educação"; o eixo dos preceitos, "em que se observa como os saberes foram tornados normativos na condução da conduta dos futuros músicos"; e o eixo dos procedimentos, "onde se procura perceber como o discurso se efetivou nas práticas, tendo em atenção as modalidades de ensino disponíveis". Estes eixos derivam diretamente dos "focos ou matrizes da experiência" que esse sujeito musical - que somos todos nós - trava com o ensino musical (PAZ, 2014, s/p). 
O problema da experiência do sujeito musical transpunha-se diretamente do Governo dos vivos (1983), com o convite de Michel Foucault para que, qualquer que fosse o tema, a experiência fosse observada nos seus três eixos constituintes: 1) o eixo da formação dos saberes; 2) o eixo da normatividade dos comportamentos; e 3) o eixo da constituição dos modos de ser do sujeito. Sugeria localizar empiricamente estes focos, mas também estabelecer entre todos a sua "correlação" (FOUCAULT, 2000, p. 41). O autor de "Vigiar e Punir" propõe, neste aspeto, que a experiência do ser humano é analisável a partir de três procedimentos distintos entre si, porque se destinam à análise de cada um dos eixos. A divisão em "Os discursos: Eixo da formação dos saberes", "Os preceitos: Eixo da normatividade dos comportamentos ou os saberes tornados normas" e "Os procedimentos: Eixo da ação social dos sujeitos" decorre diretamente desta proposta de Foucault. Como veremos em detalhe, cada um dos capítulos prolongou-se para outras longitudes teóricas, nomeadamente, da teoria social de Pierre Bourdieu e seus conceitos operatórios (e.g., habitus, campo cultural, violência simbólica).

O eixo da formação dos saberes ocupa um capítulo único, "Regras do saber-poder no subcampo musical (1868-1930)", ramificado em três subcapítulos. Na origem, existia um só texto corrido, demasiado longo e denso para ser lido duma assentada. Essa extensão inusitada era circunstância do seu modo de fazer, pois tratava-se da ampliação de um artigo sobre a constituição e natureza do conhecimento expert, em que experimentara as potencialidades de um repertório de monografias de música e educação a circular em Portugal, publicadas na cronologia mais breve de 1868-1901 (PAZ, 2013a).

Em segundo lugar, "Os Preceitos: Eixo da normatividade dos comportamentos ou os saberes tornados normais" interroga os saberes pedagógicos e os modos de fazer e de dizer. Começo, no subcapítulo "Pedagogia como normação do génio", por todos os aspetos da pedagogia que me foi possível tratar a partir da tópica dominante do génio, desde a própria emergência da pedagogia musical como um saber específico que se aplica em aulas públicas e particulares, até aspetos mais concretos da relação entre a educação individual e coletiva, mestre-discípulo, ou de uma pedagogia que pensa o corpo do aluno numa ligação estreita com a materialidade dos instrumentos (e.g., a mão do pianista).

Por sua vez, no subcapítulo "Escrita da vida e inscrição do génio" discuto o que é a biografia e suas possibilidades como dispositivo pedagógico. Os quatro itens que o compõem giram em torno de interrogações sobre: 1) que formas teve a biografia e como se difundiu no campo cultural português; 2) como se estabelecem relações de poder através da biografia (e.g., entre biógrafo, biografado e leitor) e 3) o que significa, em termos de verdade, uma biografia. Como já se antevê, este capítulo tem uma relação com a pedagogia, vindo a defender que esta é uma forma de ensinar sobre esse génio, mas sobretudo de fazer do génio a vida de cada um. A aparente linearidade esconde a desconstrução operada, onde quer conceitos específicos e quer o edifício teórico referente à ação social dos sujeitos musicais são devastados, numa demonstração de que as próprias categorias de uma biografia são, elas mesmas, completamente fabricadas e instáveis.

Finalmente, segue-se o terceiro eixo dos saberes associados à experiência musical dos indivíduos na modernidade, visíveis no extenso capítulo "Os procedimentos: eixo da ação 
social dos sujeitos", onde se versa sobre uma prosopografia, construída numa seleção de 460 fichas biográficas de dicionários de músicos (VIEIRA, 1900; CASTELO-BRANCO, 2010), posteriormente trabalhadas com informação de literatura mais recente e de pesquisa em arquivos vários.

O estudo encerra com um fecho curto, de seis páginas, onde busquei sintetizar as principais ideias do texto, esgrimir as principais conclusões, e onde agora observo a ausência de quaisquer ideias para caminhos futuros - teria perdido toda a esperança? Após uma análise detalhada desta "conversa infinita sobre o ensino musical" lançada pela pergunta de investigação (PAZ, 2014, p. 721) chego a um cúmulo conclusivo, "mesmo sabendo de antemão que a pergunta de partida há-de ressurgir intacta, não importando a dimensão da prova, o desbravamento operado pelo trabalho em busca de resposta, e não importando sequer o brilho da argumentação" (Ó, 2019, p. 25):

Ao longo destas muitas páginas, através do recurso metodológico a um inventário de monografias, a uma lista de obras de imprensa periódica, ao repertório de artigos de imprensa sobre pedagogia musical, e a uma série de vidas de artistas que se conjugam numa prosopografia de músicos, julgo ter demonstrado que o génio se tornou, com efeito, numa tecnologia de rarefação que, dentro do dispositivo da escrita e potenciado por técnicas como a escrita biográfica e a escrita pedagógica, se evidenciou no cenário cultural português como um verdadeiro dispositivo às práticas. O próprio modo de ser músico passou a ser sincronizado com o script do génio. Sobre o modo como o génio poderia ser descrito na sua implantação na sociedade portuguesa de 1868-1930, permito-me avançar que o coração destas práticas de rarefação remete ao dispositivo de escrita, firmado em duas técnicas específicas: a escrita pedagógica e a escrita biográfica. Através destas duas diferentes modalidades, o génio passou a pertencer de modo permanente no horizonte de músicos e aspirantes, senão mesmo, afinal, a uma aspiração que cabe dentro de todos nós. Descobre-se assim, num último enlace, como a imagem do génio foi tentativamente produzido à imagem e semelhança do seu criador, pois à medida que se ia instituindo o lugar do intelectual, também se foi valorizando consecutivamente o músico-intelectual, tornado o vulto mais aproximado ao génio (PAZ, 2014, p. 727).

\section{Sequência, organização e estrutura: modos de dominar o caos}

No caso da História do Ensino da Música em Portugal (1868-1930): Uma história de pedagogia e do imaginário musical, a redação viveu sempre numa luta entre o espaço que estava dado de antemão - correto, legítimo, seguro -, e o desejo de desenhar outras geografias - indisciplinadas, incertas, desconhecidas. O índice pode ser, assim, visto como o mapa dessa navegação à vista num mundo construído em diferentes capítulos, que se foram organizando até tomarem a aparência de um corpo com cabeça, tronco e membros.

Perante a divisão entre teoria e empiria, parte I e parte II, sinto um desconforto, sabendo que comecei por elucubrar uma tese em que a teoria e a prática fizessem um vai-vem, uma concertina (HORTON, 2019) que trouxesse musicalidades e daí improvisações possíveis. A obra acabada devolve-me essa manifesta falha, um lembrete da incapacidade de desenhar 
essa escrita tal como encontrara nos textos modelares de outras teses entretanto concluídas no mesmo Doutoramento em História da Educação (CABELEIRA, 2013; MARTINS, 2011). Recorda-me como a tessitura de uma discussão teórica se separou de todo o resto e do tempo em que quanto mais me afundava em questões de natureza filosófica, mais sentia necessidade de compor uma primeira imagem apenas teórica. A decisão por dividir a tese nas tradicionais partes teórica e prática foi um baixar de armas perante a batalha que, a certa altura, declarei perdida. Acredito que muitos estudantes, guiados pelo mesmo desejo, se sintam incapazes de prosseguir neste desenho. E não tendo uma experiência gloriosa com que os possa guiar, remeto para as teses e trabalhos académicos que me deram esse sopro e para o suporte sempre profícuo da co-orientação, na esperança de apesar dessa lacuna sejam mais felizes no que não fui capaz de levar até às últimas consequências. Neste sentido, diria que o aluno de doutoramento prolonga e concretiza muitos dos gestos que nós, enquanto alunos, não fomos capazes de levar até ao fim, por falta de conhecimentos, talento, tempo, vontade.

O tópico da sequência inerente à narrativa do trabalho científico pode ainda ser ventilado a propósito da ordenação dos capítulos. Por muito que o grande acervo das ciências sociais e humanas tenha vindo a crescer, amiúde encontramos no interior de cada tese um esqueleto standard, que contempla a tríade herdada da visão aristotélica: introdução, desenvolvimento e conclusão. Ainda assim, os alunos de doutoramento amiúde chegam à redação da tese sem grande noção do que implica esta articulação como um todo, ou a que poderá efetivamente corresponder qualquer uma destas partes. $\mathrm{O}$ miolo do texto doutoral remete o mais das vezes para uma estrutura ordenada, maquinal, onde se seguem, como numa parada militar, primeiro o enquadramento teórico com um estado da arte ou revisão de literatura e apresentação dos principais conceitos, depois a explicitação da metodologia, seguida da apresentação e discussão de resultados, secção essa que afinal só antecede o grande final da parada, a conclusão, e tudo isto encabeçado por uma introdução tão mais brilhante e elucidativa do problema de estudo e de todo o conteúdo da tese quanto o candidato for capaz de redigir. $\mathrm{O}$ desejo de transgredir, com consciência, esta ordenação que não parece, a muitos, natural, acaba por ter como resultado a experimentação em construções inesperadas, onde a literatura académica ganha novos coloridos. O problema situa-se quando a ordem é quebrada por ignorância dos processos? O facto é que, sempre que esta ordenação é quebrada são suspensos os laços que suportam este sistema, seja por falta de conhecimentos, seja por rebeldia declarada de quem não mais quer contribuir com o seu esforço para criar mais uma cópia que engrossará as fileiras da vasta literatura cinzenta deste mundo.

A sequência final é o terceiro aspeto a enfatizar. Até à estabilização do texto o índice foi muitas vezes testado e as diferentes experiências foram sendo consecutivamente reprovadas. Como explico na introdução, imaginei sempre que "este texto poderia ser lido por pessoas com finalidades muito diversas, eventualmente dirigidas a apenas um segmento do texto", razão pela qual "cada capítulo configura um problema em si" (PAZ, 2014, p. 19). Este poliedro de capítulos, que apenas interessaria, de uma ponta à outra, à própria autora, acabou deste modo por resultar numa falta de ligação entre os diferentes capítulos, entretanto dados, também em separado, a diferentes pessoas para revisão de texto ${ }^{2}$. Já muito perto do 
final tive de resolver esse desfasamento a partir de um ajustamento na redação das introduções que aparecem a cada capítulo.

Para perceber como se chegou à sequência final e para compreender muitas das decisões do processo de escrita, recorro também a uma camada arqueológica de apontamentos e versões anteriores da tese. Descubro, assim, a primeira versão do enquadramento teórico, datada de julho de 2011, o que significa que três anos decorreram sem que nada tivesse sido digno de mostrar e outros três passaram por cima desta versão, que entretanto, derivou noutro texto irreconhecível.

De igual modo, toda a parte empírica foi mexida vezes sem conta. $\mathrm{O}$ encaixe final numa primeira "Apresentação geral", seguida das outras três subpartes aconteceu a vésperas da entrega, quando, terminada toda a edição de texto, pude abranger o olhar sobre o caminho que o leitor poderia traçar, com maior proveito. Percebi então que a apresentação de fontes e métodos, que se encontrava até esse momento difusa entre os diferentes capítulos, bem se poderia coligir e integrar aqui, com uma discussão diferenciada para o tratamento de fontes de diferentes naturezas, como sejam as monografias, a imprensa periódica e as fichas biográficas. Essa diferenciação, que não faria qualquer sentido num formato de artigo ou paper, em que a síntese é absolutamente necessária, leva a considerar que estas decisões são inerentes ao formato que o texto toma.

Como quarto e último ponto, importa sublinhar que nem todos os capítulos foram planeados desde o início. O último capítulo corresponde à única verdadeira intenção e aspiração que acalentava desde o primeiro minuto deste processo, mas foi efetivamente a última coleção, análise e redação a ser levada a efeito. Tudo o que o antecede é, de certa forma, um longo e tortuoso caminho que precisei de tomar para chegar até aqui. Talvez por isso, apesar da muita insegurança que procurei varrer com uma justificativa sólida, plena de discussão de conceitos e mostras de grande conhecimento historiográfico (assim o tentei fazer parecer), foi sem hesitação que este capítulo prosopográfico constituiu o principal produto da tese, com a sua adaptação em livro (PAZ, 2018b) - como se tudo o resto se pudesse obnubilar como uma simples escada para chegar àquele conhecimento.

\section{Enquadramento teórico: promover um bom encontro}

O enquadramento teórico serviu como o lugar de encontro de todos os autores e textos marcantes. É aliciante pensar que a esta festa vieram muito mais pessoas do que aquelas que eu teria convidado. Tanto porque, nos encontros de pesquisadores a que fui tendo acesso continuado (Seminário de Leitura de Jorge Ramos do Ó, Seminário de Estudos de Denice Catani, Grupo de Pesquisa de Júlio Groppa Aquino) se discutiam obras que desconhecia por completo, como ainda, nesta sequência, acabei por encontrar novas ligações entre autores e problemas.

No centro da minha problematização encontram-se duas figuras conceptuais raramente conjugadas: Michel Foucault e Pierre Bourdieu. Parte da redação consistiu exatamente em justificar esta dupla conceptualização. Três razões concorriam para trazer o filósofo pós- 
estruturalista e o sociólogo crítico para o mesmo espaço de indagação: a primeira deriva do facto de ter construído a minha perplexidade sobre o ensino musical a partir de ambos os autores, refletida e exponenciada na escolha dos orientadores; a segunda de ter verificado que a maioria dos trabalhos académicos sobre ensino musical tinham quase sempre a forte linhagem num ou noutro; a terceira deriva da circunstância de, na leitura das suas obras, ter encontrado modos de problematização semelhantes, em alguns aspetos. Compreendi, a determinada altura, que tanto Foucault como Bourdieu fechavam, nas ciências sociais e humanas, um círculo onde Friedrich Nietzsche e suas intensas polémicas estavam no centro de pesquisas. Era então a minha verdadeira figura conceptual o polémico filósofo alemão, esse que eu execrara nos tempos de ensino secundário, esse que eu julgava a inspiração dos maiores criminosos do século XX, esse homem macilento que o feminismo combatia pelas suas lamentáveis afirmações...

Uma busca pelas suas biografias revela que tanto Michel Foucault como Pierre Bourdieu foram alunos diletos de Georges Canguilhem. Bourdieu conta que este professor "produziu uma contribuição decisiva para a epistemologia histórica" incidindo numa "a historicização da epistemologia" com uma "análise rigorosa" da "génese dos conceitos científicos e dos obstáculos históricos à sua emergência" (BOURDIEU, 2005, p. 58-59). É certamente esta uma das vias através das quais o pensamento nietzschiano se interiorizou na trajetória de ambos os pensadores, chegando, consabidamente, a pontos muito distintos na teorização social.

Por esta razão, dediquei uma parte importante do mergulho teórico a compreender em que se poderiam aproximar e, contra os meus próprios julgamentos, a ler Nietszche com novos olhos. A coragem de afrontar a linha que diferenciava o autor de "A distinção" do responsável pela "História da sexualidade" adveio de uma premissa dos Seminários de Leitura, em que sempre Jorge Ramos do Ó convidara os assistentes a fazerem da escrita um constante trabalho de bricolagem entre ideias de autores que poderiam parecer muito distintos, até antagónicos, sobre um ponto específico. Como explico de modo sumário, em ambas as obras, sobressai a busca perpétua do contingente. Através de análises longas, geridas através da suspeição constante de categorias de pensamento, ambos mostraram a contingência do seu valor. Afinal, o valor de uma categoria de pensamento, referindo-se com tal aparato tanto às categorias lógicas, como às que compõem a nossa escala de valores, têm por referente externo a linguagem. Neste aspeto, cada um a seu modo, desconsideraram a possibilidade de que exista qualquer essência por detrás deste modo de entender o mundo. Adotando um ponto de vista nominalista, as realidades não existem em si, nem por si. $\mathrm{O}$ valor de cada produto cultural é, antes, atribuído num incessante movimento, em que as forças sociais estão em processo contínuo (PAZ, 2014, p. 125).

Por fim, introduzi também uma nota que hoje escreveria de outro modo. Considerei que, no final das suas carreiras, "talvez quebrando ao peso da crítica, talvez pela força dos monumentos empíricos por eles criados" ambos vieram a relativizar a sua posição, "admitindo a existência de uma verdade e não pondo de parte a possibilidade de encontrar outros referentes externos, além da linguagem" (PAZ, 2014, p. 125; sublinhado no original). 
A questão nunca seria se há ou não uma verdade, ela existe e está aí, mas sempre ir ao como ela se constitui como tal, como ela constitui um espaço permanente de lutas (BOURDIEU, 2008b), premissa que conhecia, replicava, mas não havia, nesse então, interiorizado até às consequências liminares.

No que respeita a Nietzsche, reivindico a "forte afinidade com a sua obra", mas aponto que "nenhum dos seus ensaios foi diretamente refletido na investigação empírica". O filósofo alemão guardaria a sua influência "no uso específico noção de genealogia" ou história do presente, que remete para as apropriações de Michel Foucault e, mais recentemente, de Jorge Ramos do Ó. Surge também em "expedientes" muito "laterais" como "o suplemento", sendo o suplemento o nome atribuído a uma forma de escrita ensaística e literária que surge em dois curtos trechos (PAZ, 2014, p. 125), escritos com forte influência de "A origem da tragédia" e da leitura de Rosa Maria Dias (2005). A secura destas afirmações esconde aquela que foi a luta interna - em termos éticos e morais - de aceitação de Nietzsche como um autor fundacional na construção do meu pensamento e, na verdade, do intenso prazer que resultou da leitura dos seus livros, lentamente consumidos, pelas manhãs, como primeiro exercício diário, todos os dias, em pequenas doses. Nem assinala que, nos últimos dias de um outono pressentido, no corpo exangue que escrevia por rotina e dever, revendo durante horas infinitas, ao comando de um cérebro já extenuado e, por isso, muito impaciente, só as palavras de "Gaia Ciência" puderam confortar e fazer ainda sentido.

Acresce que este professor de Basileia, fascinado pela beleza e luminosidade do Norte de Itália, era também um enamorado por música e escreveu, como nenhum outro filósofo, sobre como pensou e viveu este tema. Nietzsche parecia surgir de todos os recantos. Primeiro como wagneriano, depois como anti-wagneriano, o filósofo pareceu exercer a capacidade de me fazer amar mais a música de Wagner, com a qual crescera. À medida que lia sobre sobre a relação de amizade e criação conjunta a audição envidou um prazer muito mais intenso, que logo se tornou uma experiência insuportável após iniciar a leitura das críticas ao compositor (NIETZSCHE, 1999). E se a audição de Wagner ou qualquer outro compositor se poderia dispensar no âmbito dos objetivos a que me propusera, a relevância de um personagem português tomado primeiro por Wagner e depois por Nietzsche no panorama da educação e do ensino musical tornou impossível ignorar o filósofo. De facto, o pianista, compositor e pedagogo musical, José Viana da Mota, uma das personagens centrais do estudo e que tem a virtude de agregar vários planos de análise (surge tanto na discussão das ideias pedagógicas mais abstratas como na prosopografia, em plena trajetória de ascensão social), foi um convicto wagneriano na juventude, até que conheceu a obra de Nietzsche. Não teria sido possível aproximar-me do que significava ser um adolescente português em Berlim na década de 1880 sem a leitura de todos os passos da "amizade estelar" (NIETZSCHE, 2000, p. 176) que uniu Nietzsche e Wagner num mesmo plano ético e estético. A rutura teve diversas implicações para a música europeia, para o compositor (afinal poucas) e para a escrita do filósofo (reconhecidamente muitas e profundas) (FOERSTER-NIETZSCHE, 2001; NIETZSCHE, 1999.). Trata-se afinal de um tropo da musicalidade finissecular, que teve sempre a Wagner por barómetro e em que os músicos com formação e aspiração 
intelectual reivindicavam, ainda, com mais ou menos conhecimento de causa, a sua obra mais filosófica.

Há então um processo em que o autor de uma tese não controla, em definitivo, todos os seus convidados, dando-se o irónico caso de ser uma persona non grata transformada no convidado de honra, que ora serve de esteio teórico, ora se transforma numa fonte historiográfica, ora ainda se institui como uma companhia indispensável na escrita, como um percursor de uma tão desejada libertação da palavra.

\section{O estado da arte como o excesso da falta}

Como qualquer estudante universitário, confrontada com tarefas de grande indefinição, procurei nos manuais de investigação indicações explícitas sobre o 'como se faz'. Sobre o que é como se elabora um estado da arte, sobre a diferença entre estado da arte e revisão de literatura, e outras questões congéneres, foi preciso, em primeiro lugar, documentar-me acerca do que se tratava e, em segundo lugar, compreender a dinâmica no desenho geral da investigação. Como docente, recebo sem qualquer espanto textos em que a revisão de literatura é ausente ou totalmente equivocada. Também para mim o esforço em compreender essa linha, que agora me parece óbvia, me tomou ainda desde o mestrado. Grandes clássicos da craveira de "Como se faz uma tese", por exemplo, nada esclarecem sobre este passo. Para compreender este preceito, decorreram muitas leituras, a assistência a várias comunicações e um trabalho de pares que remete para horas e horas de desabafos. A sequência foi finalmente compreendida com a partilha de uma investigação sobre instituições para cegos (AMADO, 2013), que à época esclareceu as dúvidas mais prementes. Entretanto, com a escrita de artigos científicos, sobreveio como uma fase perfeitamente definida. Mas só muito mais tarde, na preparação de aulas sobre os elementos iniciais numa pesquisa - problema, objetivos e perguntas de investigação -, consegui perceber e depois explicar os diferentes modos de consolidar esta a parte teórica da investigação e tornar inteligível o lugar exato que deveria ocupar na economia geral do texto, justificando a sua (im)prescibilidade para a definição de um problema original:

Figura 1 - Exemplos de sequência num desenho de investigação.

\begin{tabular}{|c|c|c|c|}
\hline Exemplo 1 & Exemplo 2 & Exemplo 3 & Exemplo 4 \\
\hline Tema & Tema & Tópico & Pergunta de partida \\
\hline Pergunta inicial & $\begin{array}{c}\text { Quadro de } \\
\text { referência }\end{array}$ & $\begin{array}{c}\text { Pesquisa } \\
\text { bibliográfica }\end{array}$ & $\begin{array}{c}\text { Leituras e entrevistas } \\
\text { exploratórias }\end{array}$ \\
\hline Estado da Arte & $\begin{array}{c}\text { Problema - em } \\
\text { forma de questão }\end{array}$ & $\begin{array}{c}\text { Problemática }- \\
\text { pode usar questões }\end{array}$ & Problemática \\
\hline Problemática & Objetivos & $\begin{array}{c}\text { Hipóteses ou } \\
\text { objetivos }\end{array}$ & Modelo de análise \\
\hline
\end{tabular}




\begin{tabular}{|c|c|c|c|}
\hline $\begin{array}{c}\text { Questão de } \\
\text { investigação }\end{array}$ & Hipóteses & $\begin{array}{c}\text { Questões de } \\
\text { investigação }\end{array}$ \\
\hline Metodologia & Variáveis & Método & \\
\hline & $\begin{array}{l}\text { Desenho de } \\
\text { investigação }\end{array}$ & & \\
\hline (Autor, 2014) & (Dias, 2010) & (Bell, 2004) & $\begin{array}{c}\text { (Quivy; } \\
\text { Campenhoudt, 1992) }\end{array}$ \\
\hline
\end{tabular}

Fonte: PAZ (2017)

O que hoje, graças aos exercícios de docência, me parece translúcido, era, durante o doutoramento, uma informação forçada e confusa. Se o gesto de procurar saber o que foi escrito até ao momento sobre determinado tema é constante nas indicações metodológicas, nada obriga, quando se leem alguns dos principais livros de metodologia de investigação, a ter uma etapa tão bem definida.

Nesse ínterim, consultando teses onde se fazia presente um estado da arte e ficando atenta ao que isso significava, apercebi-me das linhas básicas que vieram a definir para mim esse exercício: tratava-se garantir ao leitor o domínio do tema, a partir da demonstração de leituras integradas num texto consolidado e de demonstrar a pertinência do tema por sobre uma falta que existia nessa investigação anterior. Diante das mais de cinco dezenas de títulos recolhidos, onde se encontravam inúmeras dissertações de mestrado e doutoramento, várias revistas especializadas, monografias essenciais, como circunscrever essa falta? À medida que as regras deste jogo se iam tornando mais claras, também se foram aduzindo novas regras ao meu jogo académico, na esperança de o contornar, com um exercício demorado e detalhado de classificação de diferentes obras que me apareciam como relevantes para o meu tema.

Construí, muitas versões depois da primeira que se apresentou em 2011, até chegar a um artifício de escrita que fez do estado da arte não uma falta, mas um excesso. Após a coleção dos estudos mais importante, passei a dar um tratamento diferenciado, em que alguns títulos foram apenas consultados brevemente, outros estudos tiveram uma leitura mais atenta, mas todos foram revertendo para grandes áreas, onde a noção de génio musical ora aparecia como uma ideia forte, ora apenas como um vislumbre. Agreguei todo o material em quatro grandes temas, os quais faziam dois pares diferentes entre si. Criei entre cada par um tensionamento, não apenas como artifício de escrita, senão como forma de verdadeiramente inquirir de que é que se estava a falar quando se falava de educação e ensino musical e qual a posição da noção de génio nessa literatura. Queria ter a garantia de que esta revisão não reverteria numa mera descrição temática a partir do simples recorte temático de fichas bibliográficas. Passei então a trabalhar cada tema - já imaginando como se chegaria a uma tensão entre cada par até chegar ao resultado, onde surgem duas tensões, uma sobre o imaginário, constituída pelo par vida e instituição, e uma outra sobre a pedagogia, por sua vez composta por educação e música. 
O primeiro tensionamento "identificado" (PAZ, 2014, p. 125) - em boa verdade criado -, versa sobre o imaginário acerca da vida dos músicos, tanto nas suas biografias de um modo mais geral, como nas instituições por onde circularam. O segundo tensionamento trata das visões da educação sobre a música, onde se divisam os educadores propriamente ditos, os psicólogos da educação musical e outros peritos similares, bem como da visão da história (social, sobretudo) da música. Superabundava uma noção declarada de génio pelo que me apercebo estar não perante uma falta, mas de um excesso. Para minha enorme perplexidade, a verdadeira lacuna incidia num outro tópico insuspeito: a história do ensino musical português dos séculos XIX e XX ! Concluo que se tratava de "um tema ausente" que poderia ser interpretado como a impossibilidade de, até ao momento, ter emergido uma "história do ensino musical" enquanto "disciplina autónoma". Quanto ao conceito central, discorro que: "O génio surgiu assim não como uma falta que o meu estudo teria de suprir, mas como um excesso, um suplemento que a historiografia precisava entender como seu objeto (cf. DERRIDA, 1999)".

Na reflexão partilhada que este artigo teve durante a sua confeção, conforme me foi apontado por Clara Marques, doutoranda em Educação Artística, descubro ainda que a minha escrita mostra uma forte tendência para, também noutros exercícios e fragmentos, agregar os temas em tensionamentos - como se vê neste texto e como bem se percebe no dispositivo da tese, como se fosse um nó cego que me constitui e ampara na criação, mas que nunca antes me apercebera.

\section{Conceptualização e jogo de desconstrução de conceitos}

Comecei por procurar mostrar como a forma da tese se procurou entrosar com o seu conteúdo, embora nem sempre conseguisse levar este princípio a bom porto. Uma das modalidades de busca desse princípio de ativação do discurso ocorreu sempre na discussão de conceitos. Criou-se assim um jogo de construção-desconstrução quando, de largada, procuro dar conta do que significa a música para o sujeito moderno, desconstruindo de seguida o lugar do sujeito e da própria música na modernidade. O jogo de dar o conceito e depois desconstruí-lo repete-se em todo o trabalho, permitindo que, sem deixar de mostrar como têm sido historiados o ensino e a educação musical nos últimos dois séculos, se evidencie, logo de seguida, que são apenas discursificações. Essa visão do como foi feito opera sobretudo no subcapítulo "Para uma genealogia do génio", onde observo o modus faciendi deste conceito a partir de imagens do senso comum e de alguns filósofos, para depois passar a uma discussão a partir da área da psicologia, que, durante o século XX, agregou os campos de expertise sobre este tema.

O jogo é levado ao extremo no capítulo sobre a biografia como dispositivo pedagógico, que aponta para um plano de radicalidade mais extrema, levando-me em muitas passagens a "dançar mesmo à beira dos abismos" (NIETZSCHE, 2000, p. 231). Este trecho que desconstrói a prosopografia subsequente e, que, consequentemente, coloca em xeque tudo o que daí advém, não foi facilmente posicionado na economia geral do texto. Até chegar a este 
lugar, de onde depois se fizeram os ajustes finais, demonstrou-se que a prosopografia, minha única âncora firme e constante, assentava em terreno tectónico.

\section{Génio, o conceito como invariante discursivo}

Os meios pelos quais Júlio César se defendeu das enfermidades e dores de cabeça: enormes caminhadas, modo de vida simples, permanência ininterrupta ao ar livre, fadigas constantes - tais são, em geral, as medidas de conservação e proteção contra a extrema vulnerabilidade daquela máquina subtil e que trabalha sob alta pressão, que se chama génio (NIETZSCHE, 1988, p. 88-89)

Este excerto das "Incursões de um Extemporâneo" sugestivamente intitulado "Ainda um problema de dieta" é apenas uma das muitas formas de definir génio que surgiram nas formas discursivas de finais do século XIX a inícios do século XX e que desconhecia ao tempo da tese, mostrando bem que o doutoramento foi um ponto de partida para uma aprendizagem bem mais longa.

A procura do debate sobre o que era considerado o génio, na sociedade portuguesa deste época reverte, na verdade, da primeira intuição do orientador da tese, Jorge Ramos do Ó, que, ao ler o primeiro esboço de um projeto de investigação em finais de abril de 2008 , fortemente inspirado pelo capítulo histórico-genealógico do ensino artístico especializado que integra o "Estudo de Avaliação do Ensino Artístico" (FERNANDES et al, 2007) imediatamente apontou a falta do invariante discursivo. Sem esse invariante, a proposta não passava de uma descrição de instituições de ensino pretéritas. Esse invariante discursivo, ou seja, a ideia que sempre ocorria explícita ou implicitamente sempre que se falava de determinado tema - neste caso, do ensino da música -, sabíamos bem, era a ideia de génio. Sabíamos também que empreender um projeto que se acercasse deste tema espinhoso demandava a coragem da verdade. Desafiava-me então, de uma vez só, "a não sucumbir ante um tipo de epistemologia que valoriza a submissão ao saber herdado, a prudência e a suspeita a tudo quanto seja diferente" e a não "temer o horror" do já se via como um "risco intelectual" (Ó, 2019, p. 40).

Quantas vezes recordei esse dia em que, inicialmente a contragosto, aceitei essa orientação que colocou o meu trabalho no plano eterno do risco, obrigando-me a ser cada vez mais clara nos argumentos, mais empreendedora na busca de fontes, mais ousada na sua análise, fazendo frente às "fantasias", "demónios" e "resistências" que sempre assolavam (Ó, 2019, p. 31). Tomada esta decisão, críticas constrangedoras, oriundas menos de uma vontade de discutir um tema do que manter uma surdez secular, poderiam surgir a qualquer momento a partir de qualquer inocente pergunta sobre o tema da minha tese. Talvez por isso, optei por manter sempre um título relativamente neutro. Só mais tarde, já com um argumentário sólido, o termo "génio" aparece à luz do dia na versão em livro, Ser músico em Portugal: Trajetórias do aprender a ser génio, finais do século XIX- inícios do século XX, título em que, mais uma vez, o orientador deu um contributo decisivo, fazendo uma troca de palavras para uma expressão que eu, sem graça, remoía. 
A consciência de que seria incompreendida foi o verdadeiro móbil para trazer tanto e tão detalhado cuidado na descrição do que se estava a falar quando se falava de génio no Portugal da passagem do século XIX para o XX. Começo por apresentar a ideia de génio na parte teórica, com uma incursão no pelos dicionários de português, uma breve passagem por alguns escritos filosóficos - entre os quais desponta a noção clarividente de Walter Benjamin: "Génio é trabalho diligente!" (BENJAMIN, 2004, p. 12) - e, por último, um aprofundamento pela literatura especializada no tema, que se encontra, essencialmente, na área da psicologia da música e da educação. Esse trabalho de revisão de literatura das mais citadas revistas científicas de circulação internacional ${ }^{3}$ implicou a leitura e análise de dezenas de artigos sobre músicos bem-sucedidos e sobredotados, ou mais especificamente sobre uma série de conceitos associados ao génio (talento, vocação, aptidão, etc.). Alguns destes estudos, de larga circulação, eram muito técnicos e inicialmente, tinham sido cotejados na intenção de garantir conceitos operacionais, ou seja, aqueles a partir dos quais se poderia analisar o génio. Mas a partir de um plano de leitura de uma história do presente dei-me rapidamente conta que esta tarefa passaria a integrar o corpo de discussão do conceito, permitindo-me demonstrar como a expertise científica tinha continuado a falar de génio a partir da ampliação de vários conceitos que gravitavam em torno da ideia de génio, desde as suas origens no romantismo alemão de finais do século XVIII. Mais uma vez, o método ou modo genealógico tomava conta da direção da pesquisa, levando-me a considerar que língua, filosofia e expertise psi permitiam traçar um verdadeiro plano de análise para construir e desconstruir o conceito de génio, tal como ele circulava na sociedade portuguesa da época em questão. Como explico muito sinteticamente na conclusão, foi possível compreender o conceito a partir de dois planos, um de exterioridade, outro da criação de uma interioridade. No que respeita a um plano exterior, percebe-se que ele lança as bases para a instituição do ensino:

De que se estava a falar quando se falava de génio, nesta época? Pelo menos de três aspetos muitos diferentes, embora entrelaçados: (i) de tempo e/ou espaço, considerando o génio do lugar ou como ar do tempo, o Zeitgeist; (ii) de nação, entendendo o génio ou o caráter da nação ou de um povo, o Volksgeist; (iii) de indivíduos, tomando o génio como uma pessoa excecional. Embora todas estas aceções tenham sido relevantes para descrever e prescrever um estado de falta de génio ao ensino musical português, foi sobre o génio individual que se realizou a grande operação gramatológica que instituiu o artista como génio. Deste modo se percebe como o ensino musical precisou da ideia de génio para se cimentar. O génio do tempo e do espaço foi usado como justificativa para que em Portugal não vivificasse o génio artístico. Por sua vez, o génio nacional, capaz de se manifestar musicalmente através da espontânea produção dita popular (que teria depois de ser estilizada pelos músicos eruditos) foi a trave para defender a educação musical implantada no ensino primário, secundário, normal e até universitário (PAZ, 2014, p. 722).

Intimamente relacionado com este diagnóstico, mas partido de um plano de criação de uma interioridade, o génio foi conceituado ainda da seguinte forma: 
Por último, o génio artístico estava ligado a uma série de outros conceitos, de origens e movimentos interiores muito diversos: talento, vocação / aptidão, virtuose / virtuosidade, criança-prodígio / precocidade, herança, temperamento / personalidade / carácter, originalidade / criação / criatividade, e também educação e escolarização. Por finais do século XIX, ainda se podia aliás encontrar génio como sinónimo de temperamento, e mais tarde de personalidade ou caráter (PAZ, 2014, p. 722).

Esta noção múltipla, mas bastante corrente e até banal de génio, vai-se alterando ao longo do tempo, de tal modo que difere da noção que temos hoje, idealizada e distante, tal como se começou a esboçar por volta de meados do século XX (PAZ, 2013b). Neste impasse entre a forma, afinal, tão idealizada do génio que temos hoje, por oposição com um convívio mais banalizado de outrora, começo a suspeitar verdadeiramente da ideia de génio no plano da escrita: defendo hoje que não é nem nunca foi preciso ser um génio para escrever ou apresentar um doutoramento, embora essa tecnologia esteja interiorizada a partir do dispositivo escolar e, mais concretamente, da escrita.

\section{Conceitos operativos para analisar o génio}

Outra questão muito diferente, como já se começa a entrever, prende-se com a escolha de conceitos operativos para analisar a ideia de génio, o conceito que constitui aqui o invariante discursivo de quando se fala em ensino de música. Neste aspeto, a parte teórica falha mais uma vez, ao esconder, logo desde o índice, os conceitos operativos. São indicados conceitos como talento ou aptidão, mas esses não operacionalizam a pesquisa, antes fazem parte da constelação que suporta a ideia de génio, conforme constatei já posteriormente. Pese embora a existência de muitos outros que são aflorados, potenciados, modificados (e.g., subjetivação, habitus, interesse, campo,...), se tivesse hoje de eleger o par de conceitos que asseguram o escopo deste edifício teórico, escolheria o conceito de autoria e o capital musical. Sobre o primeiro, discorro que,

Ao colocar a escrita no centro das práticas de si, a modernidade desenvolveu, em paralelo, a função-autor (FOUCAULT, 1992). Porém, a ligação entre a vida e a obra mostram-se não apenas na ligação entre a escrita, mas também no trespasse da própria arte é por esta modalidade de apresentação de si. Esta apresentação tem, todavia, dois desdobramentos interligados. Um apresenta-se na ideia de que a vida e a obra se explicam mutuamente (GOEHR, 1992), num processo cognitivo que permute que ao mentor da obra seja atribuída a autoria da sua obra. $\mathrm{O}$ autor aparece deste modo como único responsável pela obra que assina, deixando em branco o espaço da mimesis de que é composto o resultado final. O segundo desdobramento apresenta a própria figura do autor, ele-mesmo em perpétuo movimento de desdobramento de si mesmo: tudo o que diz, mesmo para lá da obra (e.g., representação icónica; entrevistas, etc.), retorna ao núcleo centrípeto da autoria. Este cenário obriga-nos a entrever uma valorização do indivíduo na sua função-autor, mas em que se estabelece historicamente uma hierarquia, que começou por considerar como autor apenas os 
compositores e, só depois englobou também os intérpretes (inter alia, GOEHR, 1992; FULCHER, 2008) (PAZ, 2014, p. 146).

A vocação central deste estudo passou, assim, por mostrar como a função-autor se veio incorporar e acabou por ser agilizada pela noção de 'génio' (FERNANDES et al, 2007: 240ss; MARTINS, 2011). Dentro desta pequena conquista demonstrativa, saliento a interrogação de como a escrita (em particular a biográfica e também a pedagógica) se colocou ao serviço dessa construção e consequente idealização da vida do músico enquanto génio e autor de si mesmo.

O segundo termo que aqui quero colocar em evidência é o de capital musical, uma adaptação do que Bourdieu designa por capital cultural específico e que resulta de uma primeira discussão em torno das formas do capital cultural, na distinção entre estado incorporado, objetivado, institucionalizado (BOURDIEU, 1999). Apesar da sua importância na análise, nunca se explica no corpo da tese este conceito apropriado e estendido - porque decorre da tese e não o seu inverso. Utilizo, assim, indistintamente, os termos de capital específico e capital musical para distinguir o que, dentro do campo cultural, apenas seria dominado pelos músicos (e.g., instrumentos, notação musical, etc.), conforme explico numa investigação posterior (PAZ, 2018a). Graças a este conceito (implícito), percorro as práticas específicas dos músicos bem-sucedidos, considerados ou aparentados ao génio e obtenho uma das principais conclusões deste estudo:

a elite económica nunca se impôs no ensino musical como a elite cultural, nem sequer por breves aproximações. O capital musical específico dependeu muito mais da sua aquisição e desenvolvimento dentro de castas musicais, mesmo que pouco dotadas quer de capital económico, quer de capital cultural global, à maneira dos antigos artesãos [...] Pese embora os benefícios sociais advindos da passagem por esta instituição [Conservatório de Lisboa] ou outras formações congéneres, o capital musical não foi suscetível aos sequiosos avanços dos herdeiros do capitalismo burguês. A passagem efémera pelo ensino musical não lhes garantiu senão uma consagração social. Na constituição das suas elites próprias, o ensino musical mostrou-se porém muito permeável aos constrangimentos de laços sociais, aliás exercidos por todos os espetros da sociedade e não apenas pelo topo (PAZ, 2014, p. 726)

Esta conclusão, que parece de somenos importância, é aquela que definitivamente relança o génio em todo o seu esplendor, ao mostrar que se tratava de uma tecnologia profundamente eficaz para que o campo musical se tivesse consolidado a partir das suas regras, linguagens e formas de legitimação e consagração próprias. E, todavia, por falta de consciência conceptual, o conceito foi apropriado, remodelado, aplicado, sem que uma linha de teorização tivesse sido aduzida, em parte, porque imaginaria que a teoria teria ficado lá atrás....

\section{Os intercessores}


A construção do meu edifício teórico e metodológico não teria sido possível sem uma série de intercessores, ou seja, investigadores mais experimentados que mostram como utilizaram os grandes autores e os aplicam de modo particular nos seus trabalhos. Enunciamse como primeiros grandes intercessores os orientadores. Jorge Ramos do Ó trouxe-me a possibilidade de pensar a partir de uma genealogia, termo que procurei explorar a partir das formulações originais de Michel Foucault e do próprio Friedrich Nietzsche com grandes dificuldades iniciais. São sem dúvida as palavras luminosas de O Governo de Si Mesmo, mais tarde também ampliadas por um trabalho coletivo (Ó; MARTINS; PAZ, 2013) que me permitem uma apropriação da história do presente, embora também aqui nunca ouse uma definição personalizada.

Denice Catani começou essa tarefa numa aula a que assisti na Faculdade de Ciências Sociais e Humanas da Universidade Nova de Lisboa, a convite do meu antigo orientador de mestrado, António Candeias, ao discorrer sobre a sociologia crítica, e levando-me imediatamente a visualizar como poderia pensar uma tese sobre ensino de música. Já em São Paulo, consciente da necessidade de interlocução, cedo a minha orientadora brasileira me apresentou a autores como Sérgio Miceli, discípulo de Bourdieu, e Leopoldo Waizbort, especialista em Norbert Elias, que gentilmente discutiu o meu projeto.

Indico ainda a aproximação ao trabalho Susana Igayara-Souza (2011) que ainda recentemente concluíra o seu trabalho de doutoramento, com a participação de Jorge Ramos do Ó, e com quem construí de perto a minha ambição teórica e metodológica. Do ponto de vista teórico, apropriei-me em larga medida do que já tinham sido os seus agenciamentos do conceito de autor (FOUCAULT, 1992) para o campo musical e na transposição de uma série de conceitos sobre o campo cultural e o papel de cada um dos sujeitos na construção do seu capital cultural, social e económico (BOURDIEU, 1996, 2008a, 2008b).

De um ponto de vista metodológico, indico o trabalho extenso e doloroso de constituição de uma metodologia de organização e análise de fontes, que procurou experimentar o que já Igayara-Souza (2011) realizara no seu doutoramento sobre as publicações de mulheres professoras de música. O trabalho de coleção que estava a realizar na Biblioteca Nacional de Portugal e outros arquivos, sem um propósito definido, derivou, a partir daqui, num inventário de monografias sobre educação e ensino musical, sob inspiração direta do inventário comentado de Igayara-Souza. Segundo a autora, o inventário comentado tomado a partir da apropriação da metodologia de Philippe Lejeune - pode ser descrito como um arrolamento de fontes que funciona como um "texto em construção" de "tudo o que foi escrito ou publicado" em determinada época ou sobre um aspeto específico (IGAYARASOUZA, 2011, p. 55, n.r.20). A autora faz do seu inventário um capítulo da tese, passando depois à sua análise. Embora não tenha seguido o mesmo desenho, ao ser inteligível como este trabalho foi construído, tive uma indicação clara de como planear passos organizados para a análise destas monografias que, de outra forma, paciente e infinitamente, me propunha colecionar sem qualquer fim à vista.

Esta experiência de uma tese-farol, surge-me, então como a grande hipótese de trabalho pedagógico com os meus próprios alunos, que serão sempre incitados a encontrar esta tese- 
irmã, onde estão plasmados os seus temas, reivindicações teóricas e possibilidades metodológicas. Tese essa que, neste caso, é realizada por alguém já consagrado, mas que ainda pode ser contactado, interrogado, mas que pode também ser alguém completamente desconhecido, sem laço aparente. Como encontrá-la? Procurando.

$\mathrm{Na}$ premência de pensar como se faz uma tese de doutoramento em História da Educação, comecei sozinha por procurar compreender este processo a partir de uma leitura estrutural de trabalhos já finalizados e publicados (PAZ, 2012), encontrando algumas respostas efémeras para questões que começavam a atravessar o meu ofício. Mais tarde, Tomás Vallera arrastou-me no ousado gesto de inventar e de incorporar a figura do sábioaprendiz, nada menos do que aquele que se define como "alguém que estuda um problema específico e só em nome dele se autoriza a falar" (VALLERA; PAZ, 2014, p. 484). O sábioaprendiz ocupa o ingrato lugar do aluno de doutoramento de quem se espera a "produção de um saber" que não conhecemos ainda e em busca do qual temos ainda de partir, num "gesto de afastamento em relação ao que já é conhecido", por seu turno, enquadrado num "movimento de sentido contrário a um dizer banal e recidivo". Assim, o sábio-aprendiz tem este nome por ser aquele que se depara "na escrita da sua tese com dificuldades comuns a sábios e aprendizes" e é, por isso mesmo, uma figura habitada pelas "duas personagens entre as quais vai oscilando". À cautela, o investigador "permite-se apenas discorrer a respeito daquilo que inevitavelmente as aproxima: o desejo de escrita". Em suma, o sábio-aprendiz seria alguém tomado de uma inexorável "vontade de escrita", que lhe permite "tornar mais presente tanto aquilo que o aflige como aquilo a que almeja", e através da qual se vê, na sua ação local e singular, "impelido a formular um problema universal do gesto criativo". Persuadidos de sermos "ao mesmo tempo o sábio e o aprendiz da tese que escrevemos" (VALLERA; PAZ, 2014, p. 484), juntámos num só artigo uma mesma ambição genealógica a pesquisa sobre dois conceitos distintos, o de génio e o de polícia, cada um dos quais ativamente perscrutado numa ótica pós-estruturalista.

Compreendo agora que à medida que o processo de escrita avançou, também a intercessão foi ficando mais e mais próxima. Uma espécie de conquista de território que o aluno ganha para si.

\section{Comunidade de aprendizagem}

Eis um termo que absolutamente desconhecia, e que, todavia, tão intensamente vivi. Não retrocederia um passo na afirmação de que, se algo aprendi de dança, foi com os grupos de dançarinos que me acolheram, todos com a mesma intensidade de leitura por uma escrita, quase sempre individual, mas que várias vezes se transformou também a longo prazo numa escrita a várias mãos. Toda esta experiência inscreve-se na pertença original ao grupo de estudos dirigida por Jorge Ramos do Ó, o Seminário de Leitura, que comecei a frequentar em outubro de 2005, e onde travei conhecimento com os diversos investigadores com os quais aprendi quase tudo o que depois verti em tese.

Percebo hoje que esta experiência de orientação em grupo é uma forma adotada pelas universidades mais preocupadas em trazer uma renovação e inovação, por orientadores 
fortemente comprometidos com uma pedagogia iluminada pelo sócio-construtivismo e com diversas tentativas de aplicação de conceitos de comunidade de aprendizagem e de aprendizagem em rede (HUTCHINGS, 2017, p. 537). Através da orientação em grupo, pretende-se interromper uma relação mestre-discípulo que durante séculos dominou o nível de pós-graduação e trazer para a universidade uma responsabilidade mais partilhada, ativa e global. Nesta linha, a supervisão do trabalho científico não é mais vista como dependente de um sujeito, mas uma orientação partilhada por diferentes sujeitos e ações de orientação que criam um ambiente próprio. Trata-se de uma forma que tem mostrado ser extremamente eficaz no que respeita à aprendizagem, de tal modo que aumenta a probabilidade de conclusão (AGNÉ; MÖRKENSTAM, 2017).

Inclui-se nesta vertente da supervisão uma forte participação tanto do orientador como do orientado, mas também de outros professores, mesmo os jubilados, e, ao mesmo tempo, considera-se orientação a vivência em seminários, grupos de pesquisa e comunidades de investigação mais vasta, como por exemplo unidades de investigação, redes de jovens investigadores e escolas doutorais (BAKER; LATTUKA, 2010). Constitui-se aquilo que Vehviläinen e Löfstrom consideram uma nova conceptualização de supervisão que acontece, "simultaneamente" nos níveis "individual, de grupo e de comunidade" (VEHVILÄINEN; LÖFSTROM, 2016, p. 509). Resta perguntar até que ponto se trata de uma inovação, quando a universidade humboldtiana já propunha, a partir do modelo de seminários alemães, a criação de grupos de pesquisa, em que o papel central do orientador se verificava, com a ajuda de monitores, e em que o aluno era constantemente chamado a intervir como agente de uma pesquisa comum (PAZ; Ó, 2018).

Também a literatura especializada chama a atenção para a importância do trabalho de pares, embora seja reconhecida a enorme dificuldade em levá-lo a cabo regularmente, por falta de suporte socioeconómico que possa garantir a disponibilidade necessária (BOUD, 2001). Sem qualquer noção desta vantagem pedagógica, juntamente com outros bolseiros que frequentavam o mesmo Seminário de Orientação, decidimos fazer uso da nossa situação - altamente privilegiada - e, convencidos da importância da experiência de estudar em grupo, constituímos outro grupo sem a presença do mestre. Integrei quase ininterruptamente este coletivo desde as primeiras sessões de 2008 às últimas sessões de 2013, resultando num trabalho que não se contabiliza em qualquer produção ou indicador, mas que teve o seu peso na criação de laços perpétuos, que de vez em quando ainda frutificam em trabalhos individuais, pensados, discutidos e até, eventualmente, forjados em conjunto. $\mathrm{Na}$ sua espontaneidade, integrou uma série de doutorandos que se constitui - sem que então tivéssemos consciência - uma comunidade de aprendizagem (AGUILAR et al, 2010; DUFOUR et al, 2016), e que implicou, para mim, a mais significativa das aprendizagens. Procuro transmitir a importância do trabalho a pares e da constituição de grupos, uma lição sem grande mestria que tem garantido aos meus alunos a consciência de que é importante manter grupos autónomos entre pares (CORREIA; ROCHA, 2019).

Descubro, agora que eu própria mantenho grupos de orientação coletiva, e até partilhados com outros investigadores, que o trabalho de supervisão grupal pode ser reconhecidamente complementar ao trabalho de pares e de supervisão individual (DYSTHE; 
SAMARA; WESTRHEIM, 2007). Para o orientador implica, aliás, uma poupança de tempo ao "dar informação ao grupo em vez de individualmente, e partilhando alguns papéis de orientação com o grupo de pares" (HUTCHINGS, 2007, p. 537; t.m.). Para os estudantes, significa uma eficaz partilha de recursos sociais e académicos, ao "partilhar materiais de pesquisa, descobrindo o seu caminho para sair dos bloqueios ao longo dos projetos de investigação, fazendo resolução de problemas coletivamente, e fazendo encontros socais, para se encorajarem uns aos outros a prosseguir" (BEASLEY citado por HUTCHINGS, 2007, p. 537; t.m.). Na continuação dessa grande lição, também este artigo foi passado pelas mãos de orientandos e de outros colegas, para finalmente ser discutido em grupo.

\section{Deslocação para o deslocamento}

A importância da experiência de trabalho em grupo foi potenciada no Brasil, onde, em razão da deslocação para um país e uma cultura desconhecidas, vivenciei momentos de profundo desconforto as qual tive de reagir com uma reflexão sobre mim e sobre a escrita com que desejava mostrar a minha pesquisa ao mundo. Resultou daqui a incitação a um deslocamento para assumir novas buscas e experimentos de outras formas de escrita académica que, até então, nunca arriscara publicamente. Profundamente tímida e hábil garante da minha bolha de silêncio, nos seminários que Denice Catani organizou, em torno da leitura de uma obra de Maurice Blanchot, senti a imperiosidade de falar e escrever para o grupo em que se contavam investigadoras que mantinham, muitas vezes, a estratégia de silêncio que eu tão bem manuseava. Senti que a retribuição da hospitalidade seria dar-me a conhecer, o que resultou na circulação de vários textos muito curtos, trabalhados com um detalhe a que raramente me dei ao luxo: explorando sentidos e sonoridades e mantendo uma forma curta, quase aforística. Procurei aí pensar sobre as questões da escrita que me assaltavam, resultando em textos que nunca poderiam integrar a tese e que, pela sua aparente inutilidade se mantiveram no silêncio burocrático do relatório de estágio. Os problemas essenciais identificados com esse coletivo remetem para os pontos de aplicação a que sempre a escrita me transporta: o canto das sereias, a necessidade de esperar que as nuvens se adensem... Ou, em palavras mais prosaicas, o medo de enlouquecer e o tempo certo para a escrita.

No que respeita ao primeiro problema apontado, o tema do canto das sereias foi tratado de formas múltiplas, desde a experiência de pesquisar sem destino, passando pela sedução exercida por autores de grande gabarito, que o doutorando procuraria imitar. Entendi este aviso à navegação como a possibilidade de ir e não voltar para um lugar de desrazão e, neste sentido, travei longamente uma batalha pela racionalidade de poder habitar esse lugar inóspito mas atrativo para onde a escrita chamava:

Desde o interior de si, por uma experiência quase mística a que se acede sem receitas prévias, alcança-se um lugar onde é absolutamente necessário chegar, ver o que precisa de ser visto - luzes, cores, planaltos, vazios - e retornar. É a experiência acabada da viagem, de onde não é possível regressar sem que algo de fundamental mude. 
Regras, condições de visitação? Sigamos Blanchot: ter vontade de escrita, não temer a provável dor (antes, durante, depois), ter força de regresso.

Não basta visitar esse lugar. A viagem termina com e na escrita, que implica um regresso ao si, com aplicações e extensões antes impensadas. Um regresso que amplia o self no pensamento, que permite a escrita nunca antes escrita. Nesse ponto se distinguem os que completam a rota - como Ulisses - dos que se perdem no canto incompleto das sereias.

Na escrita científica, (a)onde leva esse lugar? (Pela dobra de Leibniz, Foucault e Deleuze extraíram os elementos irredutíveis do saber, luz e linguagem, visibilidade e enunciado parecem ter estado nesse topos e procurado cartografá-lo). Mais do que a uma luz, a uma cor, talvez a uma sensação, uma vertigem de sentido. E como dele se volta, em sentimento de si, concebendo, reconcebendo com outras luzes, outros ângulos, novas espessuras, novos tempos, o objecto sobre o qual se escreve - que é finalmente diferente daquele que sofreu o primeiro olhar, antes do clarão, da vertigem. Não há razão para alegrias: não é que se veja o mundo como ele realmente é. Somente uma visibilidade sobre a qual se pode escrever, uma visibilidade permitida (apenas?) do interior da própria escrita. Um ângulo único a que se chegou pelo particular e fiel caminho de si próprio - um descaminho do provável? (PAZ, 2011, s/p, [2. ${ }^{\mathrm{a}}$ sessão].

Mas é pela escrita que finalmente encontro um caminho possível e a resposta de que, não, a escrita não tem necessariamente de levar à loucura.

Enfrentemos essa pergunta que em voz baixa percorre todo o texto. $\mathrm{O}$ criador atinge o zénite ao enlouquecer - espaço desmembrado de fios que o prendem à terra? Suspendamos Blanchot. Monique Plaza (1990) perguntou-se alta voce e respondeu: não. O espaço da literatura não é o da loucura. Tocam-se, não se atravessam. Literatura implica o outro no seu ato, loucura vive em si e para si - já não precisa de nada, prendeu-se a esse lugar, numa igual impossibilidade de liberdade, mas também de razão. Loucura pode residir na literatura como cicatriz, a condição é afinal que a escrita tape a ferida (PAZ, 2011, s/p, [4. . sessão]).

E é então que compreendo e perco o medo:

Mas a eterna errância é ou não condição sine qua non para escrever, para não cristalizar o si? Regressar desse lugar de onde só a escrita pode devolver a razão na sua perda, sem dizer sempre o mesmo?

Verdade. Criação de um problema que só a escrita resolve. Confissão de Rousseau, lançamento de um sujeito verdadeiro, que se explica - sobretudo no advento da falta (Artaud). Um falso problema? Não, um problema criado dentro da escrita e que só dentro dela pode ser respondido. Quando dentro da ciência - suas regras, linguagem, trama, seu lugar de clarividência - se cria um problema, só nela e por ela faz sentido encontrar resposta: texto científico, o que se joga com as regras do campo científico (PAZ, 2011, s/p, [4. ${ }^{\mathrm{a}}$ sessão]).

Já no que concerne ao segundo tópico, talvez ainda me interrogue sobre qual será esse tempo certo da escrita. Mas dentro desta não-resposta, ficou claro que há uma certa forma de entender a situação, que é inteiramente minha, e que se prende com a aquisição da metáfora da viagem como forma de viver a investigação e a sua escrita - etapas por vezes muito desfasadas e que requerem competências diferenciadas. Pensar a escrita como a viagem 
levou-me então a recuperar, muito literalmente, a leitura de livros de viagem, com os quais encontrei novos tópicos para continuar a pensar já não tanto a escrita em geral, mas a escrita a que, pessoalmente almejaria. É talvez por isso que, no mesmo relatório de 2011, procurava colar a minha experiência imberbe de escrita com a de um autor e de uma obra que muito admirava, fora do âmbito académico:

Em 1980 saía a lume "Na Patagónia", uma obra insuperável da literatura de viagens assinada por Bruce Chatwin, um jornalista pouco conhecido e de quem nunca se acalentara esperanças no mundo artístico. A história romantizada pelo próprio autor faz constar que um dia chegou à redação do seu jornal um telegrama com um lacónico "Fui para a Patagónia" e tudo teria começado assim, entre o acaso e o capricho. Todavia, segundo recolha de textos póstuma, muito antes dessa mítica viagem, o escritor realizara vários pequenos textos, de modo continuado. Vistos de um ponto de vista diacrónico, enformam uma carreira que surgira afinal como o coroar de vários esforços e alguns romances deitados no lixo (CHATWIN, 2008).

O caricato de Chatwin e daquele que dizem ser o lugar mais inóspito do planeta tem lugar neste texto por uma simples razão: esta parece-me ser a metáfora e o manifesto perfeitos para o momento de deixar os textos e passar ao texto final (PAZ, 2011, p. 10). Deixar os textos e passar ao texto final era justamente uma das temáticas que ocupara os seminários com Blanchot, em que mais intervenções tinham sido suscitadas - e aqui a minha escrita retrai-se e não regista esse dito que se eternizou em mim. Aqui se evidencia algo que, na minha experiência, se configurou como uma pequena rebeldia de fuga à literatura académica strictu sensu, mas também aos textos que, não sendo estritamente académicos, eram aceites dentro de um círculo como autores canónicos. "Na Patagónia" como modelo para a minha escrita - na arrumação, na ironia, no modo de pensar os temas do passado no presente libertou, de certo modo, a escrita. A partir deste momento registo que as nuvens se adensaram para a escrita, abundantemente vertida e publicamente discutida desde 2011 em diante, a partir dos esboços de grandes capítulos.

Há uma certa ironia em revisitar o gesto de trazer Chatwin uma década depois. O tema da viagem interessou-me pessoalmente e, por essa razão, percorri vários best sellers sobre o mesmo tema. "O velho expresso da Patagónia" acabou por ser a minha proposta de primeira leitura para a unidade curricular de Introdução à Investigação Educacional, aceite com entusiasmo pelas docentes Joana Marques e Isabel Chagas que, na sua experiência, souberam reconhecer e acalentar sem travões o entusiasmo de trazer um texto aberto e instigante sobre a investigação... mesmo que aqui se tratasse da investigação-viagem. Até hoje este texto é indicado como primeira leitura para os alunos do 1..$^{\circ}$ ano da Licenciatura em Educação e Formação que, no meu caso, eram ainda convidados de imediato a escrever, em regime voluntário.

Primeiro dia de aulas. Sobrevivi. Começo a mudar a minha postura corporal. Olho para as pessoas e penso se são ou não 'da turma'. É preciso não me render às forças da conformação. [...] Pergunto-me se o Theroux foi uma boa malha, mas 
não pude deixar de tentar. Falou-me tanto à alma (PAZ, diário profissional, setembro de 2017).

Mais tarde, percebi que alguns dos mestrandos já conheciam e usavam este texto como 'seu' autor canónico. Isto fez-me perceber que o modo como um texto, um autor se legitima na universidade tem que ver com este pequeno pauzinho na engrenagem que o professor pode, sim, colocar. A última vez que a Patagónia foi trazida para a sala de aula trouxe ainda surpresas, pois no contexto insuspeito de um mestrado intensivo em Supervisão e Orientação Professional, gerou-se uma reflexão performativa, onde se experimentou a lateralidade que julgo importante ser trazida por textos literários para a compreensão - e vivência do processo de escrita. Dou-me conta, assim, que se algo que almejo para a escrita académica é a possibilidade de fazer com que na universidade se experimentem vários géneros de escrita.

\section{Notas finais}

Gostaria de surpreender o leitor ou leitora nos arremedos finais de uma escrita sobre escrita, para concretizar uma intuição que era antes difusa: a de que o mais importante neste artigo - ou em qualquer texto a ser trabalhado no momento - é a constituição desse mesmo texto. De facto, ao revisitar a tese de doutoramento terminada há seis anos e remetida para uma gaveta de onde raramente sai, o grande dilema residiu não em reviver, explicar e compreender esse processo, mas na organização de um artigo científico sobre esse modus faciendi. Voltei de novo a perigar à beira de um abismo assustador, sentindo que não tinha pés nem mãos para esta complicada dança que consiste em escrever no e para uma pedagogia do ensino superior, que se quer muito artística e em posse da sua história. Tomar o risco e recusar as formatações preexistentes, adentrar numa perscrutação de um trabalho já distante e, ao mesmo tempo, procurar comunicar um processo tão íntimo a outrem foram três faces de uma moeda que não parece agora tão visível. Com efeito, que distância entre a autora que se auto-depreciava enquanto procurava encontrar uma forma de escrita e a autora que mostra as faces num artigo que, tal como a tese que lhe serve de mote, aparece a lume com cabeça, tronco e membros. Sem rasto de toda a miséria e assombro com que foi escrita, de toda a esperança e desassossego que gerou. Uma distância tão grande, que foi esse o principal tópico de todas as conversas que se geraram em torno do manuscrito que, entretanto, foi apresentado e comentado por alunos e colegas, que apontaram sugestões e críticas.

Há, então, um estar-a-acontecer no texto que vive de um perigo, de uma excitação própria de quem se dispõe a entregar a vida e a razão, e que não vive numa tese, mas num processo de investigação, tenha ele que formato tiver quando for tornado inteligível e público. Fugir da loucura, do caos, implica então, conforme pude reviver de olhos abertos diante desta

escura noite da incerteza, aplicar-se no que Ó e Vallera chamam a oficina do fragmento, lembrando esse trabalho lento e meticuloso a que Benjamin se entregou, e muitos outros antes e depois dele, e que implica "uma escrita de passo a passo, de decomposição, de digressão, de transferência ou do ralenti" (Ó; VALLERA, 2020, p. 333). 
No caso deste texto, que tentativamente opera uma auto-etnografia de uma narrativatese, é justamente pelo fragmento que finalmente se encontra um caminho para regressar a terra, escapando de um mar pejado de sereias, de canto tão sedutor quanto a perdição que anunciam. Fragmento a fragmento se vão reconstruindo nexos possíveis para uma história afinal tão banal: fazer um doutoramento, viver a escrita intensamente, aprender nesse processo e depois, em respeito pelos pares, comunicar o que se aprendeu e como. Uma história de muitos séculos que este texto, mais uma vez replica, num idioma próprio e consubstanciado pelo meu ponto de vista.

\section{Notas}

1. De ora em diante, abreviado para t.m.

2. Alguns capítulos foram até revistos por mais do que uma pessoa, embora cada leitor/a tenha revisto apenas um capítulo, no máximo dois, Ana Almeida, Elisa Vieira, Gabriela Lourenço, Isabel Figueira, João Aveledo, Pedro Lisboa entre outras pessoas que, gentilmente comentaram a tese na fase de elaboração.

3. Essas revistas eram, à época, inacessíveis a quase todas as instituições portuguesas. Isabel Figueira, doou um passe de um dia nas bases de dados, com o qual pude pesquisar e guardar todos os artigos que já tinha sinalizado na literatura especializada, encontrando também outros trabalhos relevantes.

\section{Referências}

AMADO, Maria R. Hide and seek: normality issues and global discourses on blind school modern projects (late 18th-19th centuries). Lisboa: Instituto de Educação da Universidade de Lisboa. (tese de doutoramento), 2013.

ADAMS, Tony; HERRMANN, Andrews. Expanding Our Autoethnographic Future. Journal of Autoethnography, vol. 1, n. 1, 2020, p. 1-8. Disponível em < https://doi.org/10.1525/joae.2020.1.1.1>

AGNÉ, Hans; MÖRKENSTAM, Ulf. Should first-year doctoral students be supervised collectively or individually? Effects on thesis completion and time to completion. Higher Education Research and Development, vol. 37, n. 4, 2017, p. 669-682.

AGUILAR, C., ALONSO, M.J., PADRÓS, M., PULIDO, M.. Lectura dialógica y transformación en las comunidades de aprendizaje. Revista Interuniversitaria de Formación del Profesorado, vol. 67 n. 24(1), 2010, p. 31-44.

ALVES, André. Da dificuldade ou do funâmbulo seguro. Derivas, Porto, n. 1, jun. 2014, p. 11-20.

BAKER, V. L.; LATTUCA, L. R. Developmental Networks and Learning: Toward an Interdisciplinary Perspective on Identity Development During Doctoral Study. Studies in Higher Education, v. 35, n. 7, 2010, p. 807-27.

BELL, J. Como realizar um projeto de investigação. Lisboa: Gradiva, 2004.

BENJAMIN, Walter. Imagens de pensamento. Lisboa: Assírio \& Alvim, 2004.

BIESTA, Gert. Freeing Teaching from Learning: Opening Up Existential Possibilities in Educational Relationships, Studies in Philosophy and Education, v.. 34 n. 3, 2014, p. 229-243. 
BOUD, D. Introduction: Making the move to peer learning. In BOUD, D., COHEN, R. and SAMPSON, J. (Eds.), Peer learning in higher education: Learning from and with each other (p. 1-17). Londres: Kogan Page, 2001.

BOURDIEU, Pierre. As regras da arte. Lisboa: Editorial Presença, 1996.

Os três estados do capital. In: M.A. NOGUEIRA, A. CATANI, A. (orgs.), Escritos de educação. Petrópolis: Vozes, 1999.

Esboço de autoanálise. São Paulo: Companhia das Letras, 2005.

A distinção: Crítica social do julgamento. São Paulo: Zouk/EDUSP, 2008a.

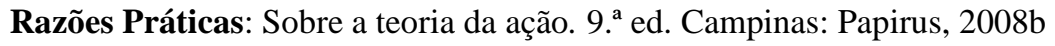

\& DARBEL, Alain. O amor pela arte: Os museus de arte na Europa e o seu público. Porto Alegre: Zouk, 2007.

CABELEIRA, Helena. O artista enquanto aluno: ensino artístico, práticas culturais e concepções de si na imprensa académica da Universidade de Lisboa (1878-2007). Lisboa: Instituto de Educação da Universidade de Lisboa. (tese de doutoramento), 2013.

CASTELO-BRANCO, Salwa (dir. $\left.{ }^{a}\right)$. Enciclopédia da música em Portugal no século XX. 4 vols. Lisboa: Círculo de Leitores/ Temas e Debates, 2010.

CHATWIN, Bruce. Anatomia da Errância. Lisboa: Bertrand Editora, 2008.

COCKER, Emma. Pay attention to the footnotes. Journal of Writing in Creative Practice, v. 2, n.2, nov. 2009, p. 139-149.

CORREIA, Cinayana Silva; ROCHA, Ana. 'Buraco - Investigação e Educação Artística em rede no ensino superior. In: F. Veiga et al., (Ed.), Envolvimento dos alunos na escola. Lisboa: Colibri, 2019, p. 179-189.

DERRIDA, Jacques. Gramatologia. São Paulo: Perspectiva, 1999.

DIAS, M.O. Planos de investigação: Avançando passo a passo. Santa Maria da Feira: Rainho \& Neves, 2010.

DIAS, Rosa M. . . Nietzsche e a música. São Paulo/Ijuí: Discurso Editorial; Editora UNIJUÍ, 2005.

DYSTHE, Olga; SAMARA, Akylina; WESTRHEIM, Kariane. Multivoiced supervision of Master's students: a case study of alternative supervision practices in higher education. Studies in Higher Education, v. 31, n. 3, jan. 2006, p. 299-318.

DUFOUR, R., DUFOUR, R., EAKER, R. e THOMAS, M. (2016). Learning by Doing A Handbook for Professional Learning Communities at Work. Bloomington: Solution Tree Press, 2016.

ELLIS, C. The ethnographic I: A methodological novel about autoethnography. Walnut Creek, AltaMira Press, 2004.

FERNANDES, D.; Ó, J.R.; FERREIRA, M.; MARTO, A.; PAZ, A; TRAVASSOS, A. Estudo de Avaliação do Ensino Artístico. Lisboa, Faculdade de Psicologia e de Ciências da Educação, 2007. Disponível em: <http://repositorio.ul.pt/bitstream/10451/5501/1/Relato\%CC\%81rioEnsinoArti\%CC\%81sticol.pdf $>$. Acesso em: 29, set., 2020.

FOUCAULT, Michel. As palavras e as coisas. São Paulo: Martins Fontes, 2000.

O que é um autor? Lisboa: Vega, 1992.

FOERSTER-NIETZSCHE, Elisabeth (ed.) Frederico Nietzsche: Correspondência com Wagner. Lisboa: Guimarães Editores, 2001.

FORTIN, Sylvie. Contribuições possíveis da etnografia e da auto-etnografia para a pesquisa na prática artística. Cena, n. 7, 2009, p. 77-88.

FULCHER, Jane. The composer as intellectual: Music and Ideology in France, 1914-1940. 2. ${ }^{\mathrm{a}}$ ed. Oxford: Oxford University Press, 2008.

GOEHR, Lydia. The imaginary museum of musical works. Oxford: Oxford University Press, 1992. 
HAMILTON, Mary Lynn; SMITH, Laura and WORTHINGTON, Kristen. Fitting the methodology with the research: An exploration of narrative, self-study and auto-ethnography. Studying Teacher Education, v. 4, n. 1, 2008, p. 17-28.

HORTON, Sarah. Exploring the 'penumbra of the non-verbal': the relationship between writing and making in a practice-based Ph.D. Journal of Writing in Creative Practice, v. 13, n. 2, 2019, p. 187-189.

HUTCHINGS, Maggie. Improving doctoral support through group supervision: analysing face-to-face and technology-mediated strategies for nurturing and sustaining scholarship. Studies in Higher Education, v. 42, n. 3, 2017, p. 533-550.

IGAYARA-SOUZA, Susana C. A.. Entre palcos e páginas: A produção escrita por mulheres sobre música na história da educação musical do Brasil (1907-1958). São Paulo: Faculdade de Educação da Universidade de São Paulo. (Tese de doutoramento), 2011.

MARTINS, Catarina S. As narrativas do génio e da salvação: A invenção do olhar e a fabricação da mão na educação e no ensino das artes visuais em Portugal (de finais do século XVIII à primeira metade do século XX). Lisboa: Faculdade de Psicologia- Instituto de Educação (Tese de doutoramento), 2011.

NIETZSCHE, Friedrich. Crepúsculo dos Ídolos. Lisboa: Edições 70, 1988.

O caso Wagner: um problema para músicos - seguido de - Nietzsche contra Wagner: Dossiê de um psicólogo. São Paulo: Companhia das Letras, 1999.

A gaia ciência. Lisboa: Guimarães Editores, 2000.

Ó, Jorge Ramos do. O Governo de Si Mesmo: Modernidade pedagógica e encenações disciplinares do aluno liceal (último quartel do século XIX-meados do século XX). Lisboa: Educa, 2003.

Fazer a mão: Por uma escrita inventiva na universidade. Lisboa: Edições do Saguão, 2019.

;VALLERA, Tomás. A oficina do fragmento: Método e processo historiográfico em Walter Benjamin. História da Historiografia, v. 13, n. 32, jan-abr, p. 331-336, 2020.

; MARTINS, Catarina S.; PAZ, Ana Luísa. Genealogy as History: From Pupil to Artist as the Dynamics of Genius, Status and Inventiveness in Art Education in Portugal. In: T. S. Popkewitz (ed.), (Re)visioning The History of Education: Transnational Perspectives on its Questions, Methods and Knowledge. Nova Iorque: Palgrave, 2013, p. 157-178.

ORR, Susan; HIND, Claire. Space and place: Writing encounters self. Journal of Writing in Creative Practice, v. 2, n. 2, nov. 2009, p. 133-138.

PAZ, Ana Luísa. Memorando - um semestre em São Paulo, 2009/2010- Projeto "Ensino da Música em Portugal (1835-1983): Uma história de pedagogia e do imaginário social”. Lisboa, Instituto de Educação da Universidade de Lisboa, (relatório de trabalho não publicado) janeiro 2001.

Ler 20 teses de doutoramento para escrever 1 em história da educação (1998-2012): Um olhar sobre a mimesis e a inventividade. In: M.J. MOGARRO, M.T.S. CUNHA (orgs.), Rituais, Espaços \& Patrimónios Escolares. Lisboa: Instituto de Educação da Universidade de Lisboa, 2012, p.1067-1076.

. A circulação individual da expertise musical em Portugal entre 1901-1930. Historia de la Educación:

Revista Interunivesitaria, Salamanca, v. 32, n.3, 2013a, p. 121-149.

. El geni i la condició imprescindible de l'escola: El pas de Pierino da Gamba per Portugal (1948-1950).

Temps de l'Educació, Barcelona, v. 44, n.1, 2013b, p. 33-48.

. Ensino da Música em Portugal (1868-1930): Uma história de pedagogia e do imaginário musical. 2015. Tese (Doutoramento em Educação - História da Educação). Instituto de Educação da Universidade de Lisboa, Lisboa, Portugal, 2014. Disponível em: <http://repositorio.ul.pt/handle/10451/18383>. Acesso em: 29, set., 2020. 
. Problema, Objetivos e Questões de Investigação [slide powerpoint]. Lisboa, Instituto de Educação da Universidade de Lisboa (material pedagógico não publicado), out. 2017.

As elites musicais em Portugal, finais do século XIX a inícios do século XX: estratégias e padrões de internacionalização. Foro de Educación, Salamanca, v. 16, n. 25, 2018a, p. 171-192. DOI: http://dx.doi.org/10.14516/fde.672

Ser músico em Portugal: Trajetórias do aprender a ser génio, finais do século XIX- inícios do século XX. Porto: SPCE/De Facto, 2018 b.

Pode o ensino superior ser mais artístico: um estudo de caso autoetnográfico sobre escrita científica e educação artística. In: P. MEMBIELA, M.I. CEBREIRO, M. VIDAL (eds.), Perspetivas docentes en la educacion superior. Vigo: Universidade de Vigo, 2020, p. 501-505.

; CAETANO, Ana Paula. Arts education and writing as research and pedagogic practice: Critical perspectives in higher education or how we became the teachers yet to come. Art, Design \& Communication in Higher Education, v. 19, n. 2, p. 185-201, 2020. DOI: 10.1386/adch_00022_1 Diponível em: https://www.ingentaconnect.com/contentone/intellect/adche/2020/00000019/00000002/art00005 Acesso em: 07, jul., 2021.

; Ó, Jorge Ramos do. A ideia de seminário e o desejo de aprender: Das primeiras iniciativas em Halle (1695) à intensidade experimental de Vincennes (1968). Em Aberto, Brasília, v. 30, n. 101, 2018, p. 147162.

PLAZA, Monique. A escrita e a loucura. Lisboa: Editorial Estampa, 1990.

QUIVY, R.; CAMPENHOUDT, L.V. Manual de Investigação em Ciências Sociais. Lisboa: Gradiva, 1992.

RIEDLER, Martina. An Art Educator's Journey of Becoming a Researcher: A Self-Reflective AutoEthnography of Identity Construction and Personal Growth. International Journal of Progressive Education, v. 12, n. 2, 2016, p. 138-148.

SILVA, Susana Mendes. To be an artist, to be a doctor of philosophy. In: Arte e Universidade. Coimbra, Universidade de Coimbra, 2016. p. $\quad$ 39-43. Disponível em: <https://www.academia.edu/30419081/To_be_an_artist_to_be_a_doctor_of_philosophy>. Acesso em: 29, set., 2020.

VEHVILÄINEN, Sanna; LÖFSTRÖM, Erika. 'I wish I had a crystal ball':discourses and potentials for developing academic supervising, Studies in Higher Education, v. 41, n.3, 2016, p. 508-524.

VIEIRA, Ernesto Dicionário biográfico de músicos portugueses: História e bibliografia da música em Portugal, 2 vols. Lisboa: Tipografia Matos Moreira \& Pinheiro, 1900.

THEROUX, P. O velho expresso da Patagónia. Lisboa: Quetzal, 2017. 


\section{Correspondência}

Ana Luísa Paz: doutorada em Educação - História da Educação pela Universidade de Lisboa, Mestra em Sociologia - Sociologia da Educação pela Universidade Nova de Lisboa e Licenciada em História pela Universidade de Lisboa. Integrada no grupo de Investigação e Ensino em Currículo, Formação de Professores e Tecnologia, exerce as funções de Professora Auxiliar no Instituto de Educação da Universidade de Lisboa e de Investigadora Integrada na UIDEF - Unidade de Investigação em Educação e Formação. Colabora com o grupo de investigação "Usos do Passado" no Centro de História da Faculdade de Letras da Universidade de Lisboa. Tem publicado sobre educação e ensino artístico numa perspetiva contemporânea e histórica.

Orcid: $\underline{0000-0003-4848-8183}$

Texto publicado em Currículo sem Fronteiras com autorização dos autores. 